\title{
EFFECT OF DRYING TEMPERATURE ON THE NUTRITIONAL QUALITY OF TIGER NUT (CYPERUS ESCULENTUS)
}

\author{
Omale, P.A, Iyidiobu, B.N, Ibu, E.J \\ Department of Agricultural and Environmental Engineering, \\ University of Agriculture Makurdi, Benue State, Nigeria
}

\begin{abstract}
The effect of drying temperature on the nutritional quality of tiger nut was studied using (AOCS) American Oil Chemists standard method in seraph oil mill Nigeria limited KM 7 Gboko road Makurdi, Benue State. Fresh Tiger nut (Cyperus esculentus) was purchased from North Bank market, Makurdi in Benue State. The samples were manually cleaned to remove foreign matters. A total of $9 \mathrm{~kg}$ of sorted tiger nut was used for the experiment and was divided into three equal parts which is $3 \mathrm{~kg}$ each for $70^{\circ} \mathrm{C}, 85^{\circ} \mathrm{C}$ and $100^{\circ} \mathrm{C}$ drying temperature. The result from the investigation indicated that higher drying temperature reduces the proximate composition of tiger nut. The moisture content ranged from 3.33\% $-4.627 \%$, protein ranged from $\mathbf{2 . 0 1 8 \%}-\mathbf{- 4 . 0 0 9 \%}$, fibre ranged from $3.018 \%-7.029 \%$, oil/fats ranged from $6.229 \%-11.977 \%$, ash ranged from $1.006 \%-1.97 \%$ with the drying temperature of $100^{\circ} \mathrm{C}$ having the least value of the measured proximate compositions and $70^{\circ} \mathrm{C}$ having the highest values of the measured proximate compositions. ANOVA on the measured proximate compositions of tiger nut revealed there's no significant difference at $\mathrm{P} \leq 0.05$ in the moisture content, but there's significant difference ( $P \leq$ 0.05) for the protein, fibre, oil/fats and ash content as the temperature increases from $70^{\circ} \mathrm{C}$ to $100^{\circ} \mathrm{C}$. Based on the findings, it is recommended that a lower temperature be used in drying of tiger nut to maintain the nutritional quality.
\end{abstract}

Key words: Drying, Nutritional quality, Tiger nut

\section{INTRODUCTION}

Tiger nut (Cyperus esculentus) is an edible perennial grasslike plant that has long been recognized for its health benefits as it is rich in fiber, protein, vitamins, minerals and natural sugars (1). It can be roasted, dried or made into refreshing milk which is very nutritive and healthy for consumption. Tiger nut "Cyperus esculentus" is an underutilized tuber which grows freely and is consumed widely in Nigeria and other parts of West Africa, East Africa, parts of Europe particularly Spain as well as in the Arabian Peninsula (2). Four hundred years ago, tiger nut, in Spanish called chufa, was cultivated in region of chufa between Sudan and Egypt on the borders of the Nile River (3). Tiger nut have been established to be very important as a result of its nutritional and medicinal constituent. One of the challenges of local processing of the nut is the drying methods (2).

According to 2, it takes some farmers about three months or more to complete the drying process depending on the temperature or sunlight in the location of drying for further processing.

Tiger nuts are traditionally dried on the floor under the sun where it is exposed to foreign materials such as stone dirt etc. This drying takes longer times to dry and since the sun cannot be regulated, the modern system of drying becomes faster through the use of oven and other methods which temperature can be regulated. This study is aimed at investigating the effect of drying temperature on the nutritional quality of tiger nut.

\section{MATERIALS AND METHOD}

A. Sample Preparation

The fresh Tiger nuts (Cyperus esculentus) used in this study was purchased from North Bank market, Makurdi in Benue State. The samples were manually cleaned to remove foreign matters such as sand, foreign materials, broken and immature nuts. A total of $9 \mathrm{~kg}$ of sorted tiger nut were used for the experiment and it was divided into three equal parts which is $3 \mathrm{~kg}$ each (which were labeled $\mathrm{A}, \mathrm{B}$ and $\mathrm{C}$ ) for $70^{\circ} \mathrm{C}, 85^{\circ} \mathrm{C}$ and $100^{\circ} \mathrm{C}$ drying temperature respectively. The $3 \mathrm{~kg}$ for each drying temperature were further divided into three equal groups of $1 \mathrm{~kg}$ and used as replications within each group of drying temperature.

\section{B. Materials}

The following material and equipment used in carrying out the experiment includes: Weighing balance, Hot air oven, Tong, Dishes of silica, nickel, aluminum, porcelain or stainless steel, Spatula, Desiccator containing dry phosphorus $P_{2} \mathrm{O}_{5}$, Calcium 


\section{International Journal of Engineering Applied Sciences and Technology, 2020 \\ Vol. 4, Issue 9, ISSN No. 2455-2143, Pages 399-403 \\ Published Online January 2020 in IJEAST (http://www.ijeast.com)}

Chloride $\left(\mathrm{CaCl}_{2}\right)$, Fume cupboard ,Water bath, Nance, Marker, Kjeldahl flasks, Heaters in fume chamber, Filter paper, volumetric flasks, Burettes, Pipettes, Conical fasks, Beakers, Markeham distillation unit, Steam generator, Sulphuric acid, Hydrochloric acid, $\mathrm{CuSO}_{4}-\mathrm{Na}_{2} \mathrm{SO}_{4}$ Catalyst mixture (ratio of mixture 1:301 of $\mathrm{CuSO}_{4}$ : of $\mathrm{Na}_{2} \mathrm{SO}_{4}$ ), Boric acid crystals, Methyl red, Ethyl alcohol, Soxhlet extraction unit, Extraction thimbles (22 x 80mm), Balance, Air oven, Water/steam bath, Cotton/glass wool (oil free), Filter papers (ashless), Digestion unit (for crude fibre), Vacuum pump, Hot air oven wash bottle ,Asbestos gloves, Muffle furnace, Desiccator and timer.

\section{Method}

\section{Nutritional Qualities Determination}

Each of the samples A, B \& C were exposed to different drying temperatures $\left(70^{\circ} \mathrm{C}, 85^{\circ} \mathrm{C}\right.$ and $\left.100^{\circ} \mathrm{C}\right)$ for 48 hours to achieve dryness under a given temperature.

\section{Moisture Content}

The moisture lost according to 4 was determined by oven drying at different temperatures $\left(70^{\circ} \mathrm{C}, 85^{\circ} \mathrm{C}\right.$ and $\left.100^{\circ} \mathrm{C}\right)$. Each of the samples were weighed into pre-weighed drying dishes and kept in oven adjusted at each level of the specified temperatures $\left(70{ }^{\circ} \mathrm{C}, 85{ }^{\circ} \mathrm{C}\right.$ and $\left.100^{\circ} \mathrm{C}\right)$. The sample were withdrawn, cooled in a desiccator and reweighed after some time. Moisture content of each sample was calculated using the equation given below

$M C(\%)=\frac{W_{2}-W_{3}}{W_{2}-W_{1}} \times 100$

Where;

$M C(\%)$ Is the moisture content in $\%, W_{1}$ Is the initial weight of crucible, $W_{2}$ Is the Weight of crucible + sample before drying, $W_{a}$ is the Weight of crucible + sample after drying

\section{Crude Protein content (Macrokjeldahl method)}

Tigernut samples $(5 \mathrm{~g})$ were mixed with $15 \mathrm{~g}$ of potassium sulphate $\left(\mathrm{K}_{2} \mathrm{SO}_{4}\right), 0.7 \mathrm{~g}$ of mercuric oxide, copper sulphate $\left(\mathrm{CuSO}_{4}\right)$ as a catalyst and digested in a long necked Kjeldhal bottles with $40 \mathrm{ml}$ concentrated sulphuric acid for approximately 2 hours. Distilled water $(200 \mathrm{ml})$ and $25 \mathrm{ml}$ sodium thiosulphate solution $(80 \mathrm{~g} / \mathrm{L})$ were added. The contents of the digestive flask were mixed and boiled until at least $150 \mathrm{ml}$ distills into the receiver. Five (5) drops of methyl red indicator solution $(0.5 \mathrm{~g} / 100 \mathrm{ml}$ ethanol $)$ were added to the mixture before titration with $0.1 \mathrm{M}$ sodium hydroxide. The percentage nitrogen obtained was multiplied by a conversion factor to get the protein (Feeding stuff-determination of nitrogen content and calculation of crude protein) as shown below.

\%6 Nitrogen $=\frac{\text { (sample titre }- \text { blank titre) } \times \text { Molwity of HCL } \times 0.014 \times \text { DF } \times 100}{\text { Weight of samplensed }}$

\section{$\%$ Protein $=\%$ Nitrogen $\times$ Coversion Factor}

\section{Ash content}

Mineral ash content was determined by heating $5 \mathrm{~g}$ of each sample in a clean dry crucible. This was charred over a Bunsen flame in a fume cupboard to destroy most of the organic matter. The heated tiger nut sample was further heated in a muffle furnace at about $500{ }^{\circ} \mathrm{C}$ for about 3 hours until white ash remains. Heated tiger nut samples were cool in a desiccator and weighed. Ash was calculated as described by Adejuyian (2016) below:

$$
\% \text { Ash (dry bass })=\frac{W_{a}-W_{1}}{W_{2}-W_{1}} \times 100
$$

Where: $W_{1}=$ Initial weight of empty crucible, $W_{2}=$ Weight of crucible + sample before Charring and Ashing, $W_{3}=$ Weight of crucible + white ash

\section{Crude fiber content}

Crude fibre was determined after boiling $5 \mathrm{~g}$ defatted sample in refluxing sulphuric acid and sodium hydroxide. $0.255 \mathrm{M}$ sulphuric acid (about $200 \mathrm{ml} \mathrm{H}_{2} \mathrm{SO}_{4}$ ) and dilute sodium hydroxide (about $0.1313 \mathrm{~N} 200 \mathrm{ml} \mathrm{NaOH}$ ). The sulphuric acid was used to disperse the sample. The mixture was heated to boiling point within 1 minute (the flask was heated in a lie big reflux condenser). The whole insoluble material was transferred to the filter paper by means of dilute hydrochloric acid. The final residue was filtered through with the aid of a pre-weighed filter paper used to line a buckner funnel connected to a vacumn pump. The insoluble matter transferred to the weighed filter paper will be dried at $\left(70{ }^{\circ} \mathrm{C}, 85^{\circ} \mathrm{C}\right.$ and $100^{\circ} \mathrm{C}$ ). The filter paper and contents were incinerated to ash. The weight of the ash was subtracted from the increase of weight on the paper and insoluble material. The differences in weight were reported as crude fibre using equation below.

\section{$\%$ Crude Fibre $=$ Loss in weight after incineration $\times 100$}

\section{Oil/Fat}

The Soxhlet Method was used. The flask was washed in an oven at $100^{\circ} \mathrm{C}$ and cooled in a desiccator and wighed. The dried sample whose weight (before drying) is known was transferred into the flask and the thimble was placed in the extractor; and weighs the flask containing about $100 \mathrm{ml}$ petroleum spirit and a reflux condenser. It was extracted for about 4hours under reflux then the residue were transferred from the thimble for further 1hour extraction and weighed.

\section{RESULTS AND DISCUSSION}

\section{A Results}

The mean values of proximate analysis of tiger nut dried at different temperature's trend and results are presented in Figure : 1 and Table 1 respectively. 
International Journal of Engineering Applied Sciences and Technology, 2020

Vol. 4, Issue 9, ISSN No. 2455-2143, Pages 399-403

Published Online January 2020 in IJEAST (http://www.ijeast.com)

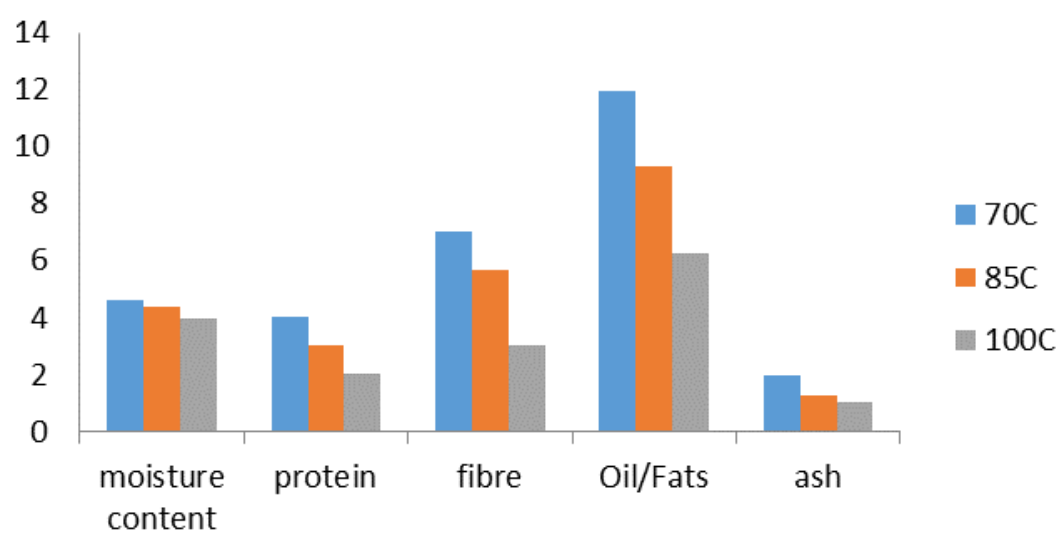

Figure 1: Tread of Proximate Components of Tiger nut dried at different temperatures

Table 1: Mean Value of the Proximate of Tiger Dried Under Different Temperature

\begin{tabular}{|c|c|c|c|c|}
\hline analysis & Temperature & $\begin{array}{r}\text { Proximate } \\
\text { N }\end{array}$ & $\begin{array}{l}\text { Drying } \\
\text { Mean }\end{array}$ & Std. Deviation \\
\hline \multirow[t]{4}{*}{ Moisture } & $70^{\circ} \mathrm{C}$ & 3 & $4.627333^{\mathrm{a}}$ & 0.5465897 \\
\hline & $85^{\circ} \mathrm{C}$ & 3 & $4.364333^{\mathrm{a}}$ & 0.6467800 \\
\hline & $100^{\circ} \mathrm{C}$ & 3 & $3.933667^{\mathrm{a}}$ & 0.1384786 \\
\hline & Total & 9 & 4.308444 & 0.5253973 \\
\hline \multirow[t]{4}{*}{ Protein } & $70^{\circ} \mathrm{C}$ & 3 & $4.009000^{c}$ & 0.0164621 \\
\hline & $85^{\circ} \mathrm{C}$ & 3 & $3.001333^{\mathrm{b}}$ & 0.0056862 \\
\hline & $100^{\circ} \mathrm{C}$ & 3 & $1.987667^{\mathrm{a}}$ & 0.0378197 \\
\hline & Total & 9 & 2.999333 & 0.8755119 \\
\hline \multirow[t]{4}{*}{ Fibre } & $70^{\circ} \mathrm{C}$ & 3 & $11.977667^{\mathrm{c}}$ & 0.0135769 \\
\hline & $85^{\circ} \mathrm{C}$ & 3 & $9.282333^{\mathrm{b}}$ & 0.2693127 \\
\hline & $100^{\circ} \mathrm{C}$ & 3 & $6.229000^{\mathrm{a}}$ & 0.2165202 \\
\hline & Total & 9 & 9.163000 & 2.4968486 \\
\hline \multirow[t]{4}{*}{ Oil } & $70^{\circ} \mathrm{C}$ & 3 & $7.029333^{c}$ & 0.2038562 \\
\hline & $85^{\circ} \mathrm{C}$ & 3 & $5.837000^{\mathrm{b}}$ & 0.2514339 \\
\hline & $100^{\circ} \mathrm{C}$ & 3 & $3.120667^{\mathrm{a}}$ & 0.0642365 \\
\hline & Total & 9 & 5.329000 & 1.7426849 \\
\hline \multirow[t]{4}{*}{ Ash } & $70^{\circ} \mathrm{C}$ & 3 & $1.969333^{\mathrm{c}}$ & 0.0083267 \\
\hline & $85^{\circ} \mathrm{C}$ & 3 & $1.261667^{\mathrm{b}}$ & 0.0485627 \\
\hline & $100^{\circ} \mathrm{C}$ & 3 & $1.005667^{\mathrm{a}}$ & 0.0295691 \\
\hline & Total & 9 & 1.412222 & 0.4332415 \\
\hline
\end{tabular}

Note: means on the same Column with same super script are not significant different while mean with different super script are significant different.

\section{DISCUSSION}

The highest moisture content was $4.627 \%$ at $70^{\circ} \mathrm{C}$ and the lowest was $3.933 \%$ at $100^{\circ} \mathrm{C}$. From the result obtained, the moisture content decreases as the temperature increases; this obviously is due to the increase of the heat which enhanced the gaining of more kinetic energy, hence rapid escape of the water molecule from the nut. The result of the moisture content is in agreement with the findings of 5 that carried out a research on the effects of temperature on the physicochemical properties of tiger nut. ANOVA revealed there's no significant difference $(\mathrm{P} \leq 0.05)$ observed in the moisture content of the tiger nut subjected to the different drying temperature of $70^{\circ} \mathrm{C}$, $85^{\circ} \mathrm{C}$ and $100^{\circ} \mathrm{C}$.

Protein content level of the tiger nut was observed to decrease as the temperature increases. The highest protein level of $4.009 \%$ was observed when the tiger nut was subjected to the 


\section{International Journal of Engineering Applied Sciences and Technology, 2020 \\ Vol. 4, Issue 9, ISSN No. 2455-2143, Pages 399-403 \\ Published Online January 2020 in IJEAST (http://www.ijeast.com)}

temperature of $70^{\circ} \mathrm{C}$ while the lowest protein level of $2.018 \%$ was observed at $100^{\circ} \mathrm{C}$. Analysis of variance revealed that there's a significant difference at $\mathrm{P} \leq 0.05$. According to 6 , tiger nut is a very good source of protein, however our finding has proven that subjecting it to higher temperature reduces the protein content significantly, this is in line with the report by 7 that heat application causes the unzipping of the hydrophobic force leading to partial or complete disruption of the primary secondary, tertiary or quaternary structure of protein molecules there by leading to reduction of the protein content of the heated sample.

The fibre content of the tiger nut was significantly different at $\mathrm{P} \leq 0.05$. The highest fibre content of $7.029 \%$ was observed at $70^{\circ} \mathrm{C}$ while the lowest fibre content of $3.018 \%$ was observed at $100^{\circ} \mathrm{C}$. The fiber content was observed to decrease as the temperature increases; this is in line with the findings of 8 in their research on the effects of heat treatments on dietary fibre. The highest value for oil/fats was observed to be $11.977 \%$ at the temperature of $70^{\circ} \mathrm{C}$ and the lowest value was observed to be $6.229 \%$ at $100^{\circ} \mathrm{C}$. ANOVA revealed a significant difference $(\mathrm{P} \leq 0.05)$ was observed in the fats/oil content of the tiger nut at the different drying temperatures.

Tiger nut has been proven to contain some amount of oil (9, 10 and 11). There was significant difference $(\mathrm{P} \leq 0.05)$ in Table 2 of the ash content of the tiger nut. The highest ash content was $1.97 \%$ at the temperature of $70^{\circ} \mathrm{C}$ and the lowest was $1.006 \%$ at the increased of $100^{\circ} \mathrm{C}$. The findings indicate that the increase in temperature reduces the ash content of tiger nut. The increased temperature caused a significant reduction in its ash content as a result the leaching of mineral elements into the oven (12).

Table 2: ANOVA of proximate Analysis of Tiger Nut Dried under Different Temperature

\begin{tabular}{|c|c|c|c|c|c|c|}
\hline \multicolumn{2}{|c|}{ Proximate Analysis } & Sum of Squares & Df & Mean Square & $\mathbf{F}$ & Sig. \\
\hline Moisture & $\begin{array}{c}\text { Between } \\
\text { Groups }\end{array}$ & 00.736 & 2 & 00.368 & 1.499 & $0.296^{\mathrm{NS}}$ \\
\hline & $\begin{array}{c}\text { Within Groups } \\
\text { Total }\end{array}$ & $\begin{array}{l}01.473 \\
02.208\end{array}$ & $\begin{array}{l}6 \\
8\end{array}$ & 00.245 & & \\
\hline Protein & $\begin{array}{c}\text { Between } \\
\text { Groups }\end{array}$ & 06.129 & 2 & 03.064 & 5302.664 & $0.000 *$ \\
\hline & $\begin{array}{c}\text { Within Groups } \\
\text { Total }\end{array}$ & $\begin{array}{l}00.003 \\
06.132\end{array}$ & $\begin{array}{l}6 \\
8\end{array}$ & 00.001 & & \\
\hline Fibre & $\begin{array}{c}\text { Between } \\
\text { Groups }\end{array}$ & 49.635 & 2 & 24.817 & 622.538 & $0.000 *$ \\
\hline & $\begin{array}{c}\text { Within Groups } \\
\text { Total }\end{array}$ & $\begin{array}{c}00.239 \\
49.874\end{array}$ & $\begin{array}{l}6 \\
8\end{array}$ & 00.040 & & \\
\hline Oil & $\begin{array}{l}\text { Between } \\
\text { Groups }\end{array}$ & 24.078 & 2 & 12.039 & 331.642 & $0.000 *$ \\
\hline & $\begin{array}{c}\text { Within Groups } \\
\text { Total }\end{array}$ & $\begin{array}{l}00.218 \\
24.296\end{array}$ & $\begin{array}{l}6 \\
8\end{array}$ & 00.036 & & \\
\hline Ash & $\begin{array}{c}\text { Between } \\
\text { Groups }\end{array}$ & 01.495 & 2 & 00.747 & 679.125 & $0.000 *$ \\
\hline & $\begin{array}{c}\text { Within Groups } \\
\text { Total }\end{array}$ & $\begin{array}{l}00.007 \\
01.502\end{array}$ & $\begin{array}{l}6 \\
8\end{array}$ & 00.001 & & \\
\hline
\end{tabular}

\section{Note: * represent significant effect while ${ }^{\mathrm{NS}}$ represent no significant effect. \\ IV. CONCLUSION}

This study reveals that drying as a processing method affects the proximate value of tiger nut. The proximate composition of the tiger nut dried at different temperature $70{ }^{\circ} \mathrm{C}, 85^{\circ} \mathrm{C}$ and $100^{\circ} \mathrm{C}$ were affected by a decrease in moisture content, protein, fibre, oil/fats, and ash content as temperature increases. ANOVA of the measured proximate composition of tiger nut reveals there's no significant difference $(\mathrm{P} \leq 0.05)$ in the moisture content, but significant difference $(\mathrm{P} \leq 0.05)$ was observed in the protein, fibre, oil/fats and ash content. Based on this study, it is recommended that drying of tiger nut should be carried out at a lower temperature, possibly lower than $70^{\circ} \mathrm{C}$ to avoid reduction of the proximate compositions of tiger nut.

\section{REFERENCES}

1. Shaker, M. A., Ahmed, M. Gaafar, Amany M. Basuny and Shereen L. Nassef (2009). Chufa Tubers (Cyperus esculentus L.): As a New Source of Food. World Applied Sciences Journal 7 (2): 151-156

2. Abaejoh, R., Djomdi, I. and Ndojouenkeu, R. (2006).Characteristics of tiger nut (Cyperus esculentus) tubers and their performance in the 


\section{International Journal of Engineering Applied Sciences and Technology, 2020 \\ Vol. 4, Issue 9, ISSN No. 2455-2143, Pages 399-403 \\ Published Online January 2020 in IJEAST (http://www.ijeast.com)}

production of a milky drink. J. Food Process. Preserv., 30: (pp 145-163)

3. Obadina, A.O., Oyawole, O.B and Ayoola, A.A. (2008). Quality assessment of Gari produced using rotary drier: In Food Processing, Methods, Techniques and Trends. Edited by Valerie C Belling house. Nova Science Publishers.

4. Adejuyian, J.A. (2011). Tiger nut processing: its food uses and health benefits. Am J Food Technol. 6(3): (pp 197-201)

5. Onovo, J. C. and Ogaraku, A. O. (2007). Studies on some Microorganisms Associated with exposed tiger nut (Cyperus esculentus L.) Milk. Journal of Biological Sciences, 7 (8):1 (pp 548-1550)

6. Okafor, J.N., Mordi, J.I., Ozumba, A.U., Solomon, H.M. and Olatunji, O. (2003). Preliminary studies on the characterisation of contaminants in tiger nut (yellow variety). In: Proceedings of 27th Annual Conference and General Meeting of Nigerian Institute of Food Science and Technology Kano. (pp.210- 211).

7. Miroslawact, K., Porzuck, H. and Malgorzatoe, K. (1997). Effect of Heat Treatment on Chemically Modified Proteins of Legume Seeds. J. Food Chem., 58(3): pp 221.

8. Chang, Ming-Cheng (1986). The Effect of Heat Treatments on Dietary Fiber As Assessed by Chemical Analysis and Scanning Electron Microscopy. Master's Thesis, University of Tennessee, 1986.

https://trace.tennessee.edu/utk_gradthes/3724

9. Oyedele O.A. and Ogunnale A.F. (2018). The Effects of Drying Temperatures on some Physicochemical Properties of Extracted Tiger Nut (Cyperus Esculentus) Oil. World Journal of Engineering Research and Technology.

10. Adel, A. A. M., Awad, A. M., Mohamed, H. H. and 2Iryna, S. (2015). Chemical composition, physicochemical properties and fatty acid profile of Tiger Nut (Cyperus esculentus L) seed oil as affected by different preparation methods. International Food Research Journal 22(5): (pp 1931-1938) 2015

11. Akinoso R., Igbeka J. and Olayanju T. (2006) Process Optimization of Oil Expression from Sesame Seed (Sesamum indicum Linn.). Agricultural Engineering International: the CIGR Ejournal. Manuscript FP 06 011, December, 2006;

12. Okorie, S.U and Nwanekezi, E. C. (2014). Evaluation Of Proximate Composition and Anti-nutritional Factors Of Cyperus esculentus (Tiger nut) As Influenced By Boiling Journal of Environmental Science, Toxicology and Food Technology (IOSRJESTFT) e-ISSN: 2319-2402,p- ISSN: 2319-
2399. Volume 8, Issue 7 Ver. II (July. 2014), (pp70-

73) www.iosrjournals.org 